Vol. 2 No. 2 Juli 2020

\title{
TANGGUNGJAWAB NAZHIR KOPERASI SYARIAH SEBAGAI LKS PWU DALAM PENGELOLAAN WAKAF UANG MELALUI APLIKASI FINTECH
}

\author{
Siti Nurhayati, Nurjamil \\ Institut Manajemen Koperasi Indonesia \\ sitinurhayati@ikopin.ac.id,nurjamil@ikopin.ac.id \\ Naskah dikirim : 9 Juni 2020 \\ Naskah diterima untuk diterbitkan : 15 Juni 2020
}

\begin{abstract}
This research was conducted to determine the form of Islamic cooperative nazhir responsibilities as PWU LKS in the management of waqf especially for a loss case in the management of waqf money. The study was a qualitative analytical study with a normative juridical approach. Data obtained through library research and field research and then analyzed qualitatively. This research was conducted in the city of Bandung, in this case the object of the study was the Sharia Cooperative that had been designated as a nazhir waqf for money by the Indonesian Waqf Board. The study concluded that if problems in the management of waqf money such as the occurrence of problematic financing or NPF, occured due to Nazir errors, either due to deliberate or negligence and / or due to non-consideration of the principle of prudence, then Nazir can be held liable according to the responsibility based on the error (based on error) on fault). This is regulated in the Civil Code (hereinafter abbreviated as the Civil Code) specifically contained in Articles 1365, 1366 and 1367. If some provisions relating to the principle of responsibility based on errors can be proven, Nazirs were required to compensate and return the endowment funds. Conversely, if the problems occured are not due to Nazir's fault, Nazir cannot be held accountable, both morally and legally. Compensation for wakaf assets shall be borne by other parties who cooperate with Nazir as stipulations regarding defaults or acts against the law stipulated in the Civil Registry
\end{abstract}

\section{Keywords: Responsibility, Nazhir Wakaf Money, PWU LKS, Fintech}

\begin{abstract}
Abstak
Penelitian ini dilakukan untuk mengetahui bentuk tanggungjawab nazhir koperasi syariah sebagai LKS PWU dalam pengelolaan wakaf terutama apabila terjadi kerugian dalam pengelolaan wakaf uang. Penelitian yang dilakukan merupakan penelitian kualitatif yang bersifat deskriptif analitis dengan pendekatan yuridis normatif. Data diperoleh melalui penelitian kepustakaan (library research) dan penelitian lapangan (field research) dan selanjutnya dianalisis secara kualitatif. Penelitian ini dilakukan di kota Bandung dalam hal ini yang menjadi obyek penelitian adalah Koperasi Syariah yang telah ditetapkan sebagai nazhir wakaf uang oleh Badan Wakaf Indonesia. Penelitian menyimpulkan bahwa apabila masalah dalam pengelolaan wakaf uang seperti terjadinya pembiayaan bermasalah atau NPF, terjadi karena kesalahan nazhir, baik karena kesengajaan maupun kelalaian dan atau karena tidak diperhatikannya prinsip kehati-hatian, maka nazhir dapat dimintakan pertanggungjawaban sesuai dengan tanggungjawab yang didasarkan pada kesalahan (based on fault). Hal tersebut diatur dalam Kitab Undang-Undang Hukum Perdata (selanjutnya disingkat KUHPerdata) khususnya terdapat dalam Pasal 1365, 1366 dan 1367. Apabila beberapa ketentuan yang berkaitan dengan prinsip tanggung jawab berdasarkan kesalahan dapat dibuktikan, maka nazhir diharuskan mengganti kerugian dan mengembalikan dana wakaf tersebut. Sebaliknya apabila masalah yang terjadi bukan karena kesalahan nazhir, maka nazhir tidak dapat dimintakan pertanggungjawabannya, baik secara moral maupun secara hukum. Ganti kerugian atas harta
\end{abstract}


Vol. 2 No. 2 Juli 2020

wakaf dibebankan kepada pihak lain yang bekerjasama dengan nazhir sebagaimana ketentuan mengenai wanprestasi atau perbuatan melawan hokum yang diatur dalam KHPerdata

Kata kunci: Tanggungjawab, Nazhir Wakaf Uang, LKS PWU, Fintech

\section{PENDAHULUAN}

Pada dasarnya dalam Islam dikenal dua sistem distribusi kekayaan utama. Pertama, yaitu disribusi komersial dan mengikuti mekanisme pasar melalui kegiatan ekonomi dan kedua distribusi yang bertumpu pada aspek keadilan sosial masyarakat melalui konsep zakat, infaq, shadaqah, harta warisan dan wakaf. ${ }^{1}$ Wakaf merupakan salah satu bentuk filantropi yang sudah dikenal dan dipraktikkan dalam peradaban Islam sejak zaman Nabi Muhammad saw, para sahabat sampai masa kekhalifahan Islam dengan kontribusi yang cukup signifikan. ${ }^{2}$ Begitu pentingnya wakaf politik hukum Islam di Indonesia telah mengakomodasinya dalam hukum positif yang ditandai dengan lahirnya Undang-undang Nomor 41 Tahun 2004 Tentang Wakaf (selanjutnya disebut Undangundang Wakaf) bahkan pada Rencana Pembangunan Jangka Menengah (RPJMN) 20202024 pemerintah menaruh perahtian besar terhadap pengembangan sektor ekonomi syariah yang salah satunya adalah mendorong perbaikan dan transparansi, akuntabilitas, kepemilikan, dan profesionalisme dalam pengelolaan dana sosial keagamaan dan mengoptimalkan pemanfaatannya bagi pelaksanaan pembangunan. ${ }^{3}$

${ }^{1}$ Lihat Euis Amalia, Keadilan Ditributif dalam Ekonomi Islam, Penguatan LKM dan UKM di Indonesia, Jakarta: Rajagrafindo Persada, 2009, hlm. 119

${ }^{2}$ Sejarah mencatat mengenai masa pemerintahan Dinasti Umayyah dan Abasiyyah sebagai masa keemasan pengelolaan wakaf. Bermodal pengelolaan harta wakaf yang profesional, dinasti-dinasti Islam mampu menyejahterakan rakyatnya. Pada zaman keemasan Islam, wakaf tak hanya dikelola dan didistribusikan untuk orang-orang fakir dan miskin saja, tetapi menjadi modal untuk membangun lembaga pendidikan, membangun perpustakaan dan membayar gaji para stafnya, mengaji para guru, serta beasiswa untuk para siswa dan mahasiswa. Rumah sakit pun dibangun di berbagai kota dengan dana wakaf. Semua biaya operasional rumah sakit ditanggung dari dana wakaf. Gaji dokter, perawat, hingga obat-obatan ditanggung dana wakaf. Sehingga, rakyat miskin sekalipun bisa mendapatkan pelayanan kesehatan yang prima secara cuma-Cuma. Lihat https://bwi.or.id/index.php/in/publikasi/artikel/1692-sejarah-wakaf-2-habis.html (Diakses pada tanggal 25 Juni 2019)

${ }^{3}$ Menteri Perencanaan Pembangunan Nasional/Kepala Badan Perencanaan Pembagunan Nasional, Indonesia Menuju Pusat Ekonomi dan Keuangan Syariah Dunia, Materi 
Vol. 2 No. 2 Juli 2020

Potensi wakaf tanah di Indonesia saat ini nilainya mencapai nilai Rp. 2000 triliun, sementara wakaf uang atau tunai (cash waqf) jumlahnya dapat mencapai Rp 180 triliun, ${ }^{4}$ Dalam perkembagangannya, wakaf tidak hanya berupa tanah saja, tetapi terus berkembang sejalan dengan perkembangan ilmu pengetahuan dan ijtihad para ulama dan terus berintegrasi dengan pesatnya pertumbuhan ekonomi, sehingga kemudian dikenal istilah wakaf produktif yang dapat berupa wakaf uang (cash waqf), wakaf saham, wakaf perusahaan, bahkan linkeded sukuk waqf dll yang terus berwujud menjadi sebuah kekuatan ekonomi yang sangat besar dan dapat menawarkan solusi dalam masalah pembangunan nasional. ${ }^{5}$

Khusus mengenai wakaf uang, Pasal 28 Undang-Undang Nomor 41 Tahun 2004 Tentang Wakaf (selanjutnya ditulis Undang-Undang Wakaf) menyebutkan bahwa wakif dapat mewakafkan benda bergerak berupa uang melalui Lembaga Keuangan Syariah (LKS). Dalam hal ini lembaga tersebut kemudian disebut Lembaga Keuangan Syariah Penerima Wakaf Uang (selanjutnya ditulis LKS PWU), yang terdiri dari Bank Syariah dan Unit Usaha syariah (UUS). Dalam Penjelasan Pasal 4 angka (3) Undang-Undang Nomor 21 Tahun 2008 Tentang Perbankan Syariah (selanjutnya ditulis UUPS) dinyatakan bahwa bahwa: Bank Syariah dan Unit Usaha Syariah dapat menghimpun dana sosial yang berasal dari wakaf uang dan menyalurkannya kepada pengelola wakaf (nazhir) sesuai dengan kehendak pemberi wakaf (wakif) dan juga koperasi syariah baik itu Koperasi Simpan Pinjam dan Pembiayaan Syariah (KSPPS) maupun Lembaga Keuangan Mikro Syariah Baitul Maal Wattamwil (BMT).

Dalam pengelolaan wakaf uang maka posisi LKS PWU dalam hal ini adalah koperasi syariah adalah sebagai nazhir wakaf uang yang mempunyai tugas dan tanggungjawab sebagaimana diatur dalam Pasal 9 sampai dengan Pasal 12 Undangundang wakaf. Bagaimana tanggungjawab nazhir LKS PWU koperasi syariah dalam

High Level Discussion pada Muktamar IV Ikatan Ahli Ekonomi Islam(IAEI), Jakarta 23 Agustus 2019

4 http://www.bwi.or.id/index.php/ar/component/content/article/80-databasedan-potensi-wakaf.html

5. Bandingkan dengan Imam T Saptono, "Pengembangan Instrumen Wakaf Berbasis Investasi Sosial, Studi Wakaf Linkeded Sukuk", Al-Awqaf, Jurnal Wakaf dan Ekonomi Islam, Vol. 11, No: 2, Jakarta: Badan Wakaf Indonesia, 2018, hlm. 120 
Vol. 2 No. 2 Juli 2020

mengelola wakaf uang apabila terjadi permasalahan seperti pembiayaan bermasalah dan lain lain menurut hukum menjadi sangat menarik untuk diteliti lebih jauh.

\section{METODE PENELITIAN}

Spesifikasi penelitian ini adalah penelitian deskriftif kualitatif yaitu penelitian yang menggambarkan tentang peraturan perundang-undangan yang berlaku dikaitkan dengan teori-teori hukum dan pelaksanaan hukum hukum positif dimaksud dalam kaitannya dengan pengelolaan wakaf uang melalui fintech. Metode pendekatan yang digunakan dalam penelitian ini adalah metode pendekatan yuridis normatif. Pendekatan dimaksud adalah penelitian ditinjau dari sudut hukum dan peraturan perundang-undangan tertulis sebagai data sekunder dan studi kepustakaan saja. ${ }^{6}$

\section{PEMBAHASAN}

\section{Wakaf Uang}

Kata "wakaf" adalah mashdar (kata dasar) dari kalimat waqafa-yaqifu-waqfan". Dalam bahasa arab kata "waqafa" maksudnya adalah berhenti dari berjalan. ${ }^{7}$ Secara etimologi, wakaf adalah al-habs (menahan) sedangkan secara terminologi yaitu: “ tahbisul ashl wa tasbiilul manfa'ah (menahan suatu barang dan memberikan manfaatnya). ${ }^{8}$ Berdasarkan pada Pasal 1 angka (1) Undang-Undang Wakaf, wakaf adalah "Wakaf adalah Perbuatan hukum wakif untuk memisahkan dan/ atau menyerahkan sebagiann harta miliknya untuk selamanya atau untuk jangka waktu tertentu sesuai dengan kepentingannya atau untuk keperluan ibadah untuk kepentingan ibadah dan/atau kesejahteraan umum menurut syariah".

Menurut Ismail Nawawi wakaf dapat dibagi menjadi tiga: ${ }^{9}$

\footnotetext{
6 Soerjono Soekanto dan Sri Mamudji, Penelitian Hukum Normatif Suatu Tinjauan Singkat, Jakarta: PT. Raja Grafindo Perkasa, 2001, hlm. 12

${ }^{7}$ Syaikh Muhammad bin Shalih al-Utsaimin, Panduan Wakaf dan Wasiat Menurut AlQuran dan al-Sunnah, Jakarta: Pustaka Imam Asy-Syafi'i, 2008, hlm. 1

8 Bandingkan dengan Juhaya S. Praja, Perwakafan di Indonesia; Sejarah, Pemikiran, Hukum, dan Perkembangannya, Bandung: Yayasan Piara, 1997, hlm. 6 245

9 Ismail Nawawi, Fikih Muamalah Kontemporer, Bogor: Ghalia Indah, 2012, hlm. 244-
} 
Vol. 2 No. 2 Juli 2020

1. Wakaf langsung, yaitu wakaf yang memberi pelayanan langsung untuk orang-orang yang berhak, seperti sekolah, masjid, dan rumah sakit.

2. Wakaf produktif, yaitu wakaf harta yang digunakan untuk kepentingan produksi, yang manfaatnya bukan kepada benda wakaf secara langsung, tetapi dari keuntungan bersih hasil pengembangan wakaf yang diberikan kepada orang - orang yang berhak sesuai tujuan wakaf.

3. Wakaf tunai, yaitu wakaf yang berupa uang. Pada masa kejayaan Islam, wakaf uang dimanfaatkan untuk dua tujuan. Pertama, untuk dipinjamkan kepada orang-orang yang membutuhkan dan setelah terpenuhi kebutuhannya maka uang tersebut dikembalikan lagi untuk dipinjamkan kepada orang lain tanpa mengambil keuntungan apapun dari peminjam Kedua, wakaf untuk keperluan produktif

Selanjutnya mengenai harta benda yang dijadikan obyek wakaf juga diatur dalam Pasal 1 ayat (5) Undang-undang Wakaf dengan ketentuan bahwa benda tersebut adalah harta yang memiliki daya tahan lama dan/atau memiliki manfaat jangka panjang serta memiliki nilai ekonomi menurut syariah termasuk diantaranya adalah uang. Menurut jenis bendanya wakaf dalam hal ini benda yang memiliki nilai atau harga (Muhammad Abdi Abdullah Al-Kabisi, 2004) dapat dibedakan menjadi dua, yaitu benda bergerak seperti uang, saham, surat berharga, surat utang negara, hak kekayaan intelektual seperti (hak cipta, hak merek, hak paten, hak desain industri, dll), logam mulia kendaraan, dll dan wakaf benda tidak bergerak yaitu wakaf tanah dan bangunan atau benda yang berdasarkan tonasenya menurut hukum dianggap benda tidak bergerak seperti kapal tangker, dll.

Berdasarkan kualifikasi wakaf di atas, wakaf uang dapat dikaegorikan sebagai wakaf benda bergerak. Wakaf uang sering diistilahkan dengan wakaf tunai (cash waqf) merupakan wakaf berupa uang tunai yang diinvestasikan ke dalam sector-sektor ekonomi yang menguntungkan dengan ketentuan persentase tertentu digunakan untuk pelayanan sosial (Abubakar, dkk., 2006). Menurut Murat Cizakca, sebagaimana dikutip oleh (Siska Lis Sulistiani, 2017) wakaf uang pertama kali dipakai pada masa Utsman di Mesir, di akhir abad ke-16 (1555-1823 M) dimana konsep wakaf uang ini semakin popular setelah Profesor Mannan mensosialisasikannya di Bangladesh melalui Social Investment Bank 
Vol. 2 No. 2 Juli 2020

Limited (SIBL). SIBL membuat sertifikat wakaf tunai (Cash Waqf Certificate) untuk mengumpulkan dana dari orang kaya dan membagi perolehan wakaf tunai yang telah dikumpulkan kepada orang-orang miskin.

Di Indonesia konsep wakaf uang tersendiri diakui secara hukum sebagaimana diatakan dalam Pasal 16 ayat (1) Undang-undang Wakaf bahwa Harta benda wakaf terdiri dari: benda tidak bergerak dan benda bergerak. Menurut Pasal 16 ayat (3) Undangundang Wakaf, benda bergerak sebagaimana dimaksud pada ayat (1) adalah harta benda yang tidak bisa habis karena dikonsumsi, meliputi : uang, logam mulia, surat berharga, kendaraan, hak atas kekayaan intelektual, hak sewa dan benda bergerak lain sesuai dengan ketentuan syariah dan peraturan perundang-undangan yang berlaku. Dalam Pasal 28 Undang-undang Wakaf dinyatakan bahwa Wakif dapat mewakafkan benda bergerak berupa uang melalui Lembaga Keuangan Syariah yang ditunjuk oleh Menteri. Lebih lanjut lagi dalam Pasal 29 Undang-undang Wakaf diatur mengenai mekanisme wakaf uang, yaitu

1. Wakaf benda bergerak berupa uang sebagaimana dimaksud dalam Pasal 28 dilaksanakan oleh Wakif dengan pernyataan kehendak Wakif yang dilakukan secara tertulis.

2. Wakaf benda bergerak berupa uang sebagaimana dimaksud pada ayat (1) diterbitkan dalam bentuk sertifikat wakaf uang.

3. Sertifikat wakaf uang sebagaimana dimaksud pada ayat (2) diterbitkan dan disampaikan oleh lembaga keuangan syariah kepada Wakif dan Nazhir sebagai bukti penyerahan harta benda wakaf.

\section{Koperasi Syariah}

Koperasi merupakan lembaga ekonomi berbasis demokrasi, artinya gerakan koperasi lebih mengedepankan prinsip-prinsip yang berpihak kepada kepentingan rakyat, sehingga konsep ini telah dipilih jauh-jauh hari oleh para pendiri bangsa sebagai lembaga yang paling sesuai dengan nilai-nilai kebangsaan yang telah lama hidup di Indonesia. ${ }^{10}$ Sebagai bentuk nyata keseriusan bangsa Indonesia dalam menggerakan ekonomi koperasi

10 Bandingkan dengan Ramudi Arifin, Koperasi Sebagai Perusahaan, Jatinangor: Ikopin Press, 2013 
Vol. 2 No. 2 Juli 2020

maka lahirlah sekian banyak peraturan terkait koperasi, lahirnya Undang-Undang Republik Indonesia Nomor 17 Tahun 2012 sebagai pengganti undang undang Nomor 25 Tahun 1992 Tentang Perkoperasian yang kemudian dibatalkan oleh Putusan Mahkamah Agung No.: 28/PUU-XI/2013 juga merupakan bagian penting tentang perkembangan koperasi dari sisi regulasi.

a. Definisi Koperasi Syariah

Koperasi syariah merupakan badan usaha koperasi yang menjalankan usaha-usahanya dengan prinsip syariah islam yaitu al-quran dan assunnah. Secara teknis koperasi syariah bisa dibilang sebagai koperasi yang prinsip anggota dan kegiatannya berdasarkan syariah islam. ${ }^{11}$

b. Prinsip-prinsip koperasi syariah

Dalam menjalankan usahanya, koperasi ini memiliki beberapa prinsip yang sesuai dengan konsep syariah. Adapun beberapa prinsip koperasi syariah adalah sebagai berikut:

1) Kekayaan merupakan amanah dari Allah swt dan tidak bisa dimiliki sepenuhnya oleh siapapun secara mutlak;

2) Setiap manusia berhak dan diberi kebebasan untuk bermu'amalah selama hal tersebut sesuai dengan ketentuan syariah;

3) Umat manusia adalah khalifah Allah dan pemakmur di muka bumi ini;

4) Menjunjung tinggi keadilan, serta menolak semua yang berhubungan dengan ribawi dan pemusatan sumber ekonomi pada sekelompok orang;

c. Tujuan dan Peran Koperasi Syariah

1) Membangun dan mengembangkan potensi dan kemampuan anggota pada khususnya, dan masyarakat pada umumnya, guna meningkatkan kesejahteraan sosial ekonominya;

2) Memperkuat kualitas sumber daya insani anggota, agar menjadi lebih amanah, professional (fathonah), konsisten, dan konsekuen (istiqomah) di dalam menerapkan prinsip-prinsip ekonomi islam dan prinsip-prinsip syariah islam;

11 https://kementeriankoperasi.com/pengertian-koperasi-syariah/ (diakses pada tanggal 27 Juli 2019) 
Vol. 2 No. 2 Juli 2020

3) Berusaha untuk mewujudkan dan mengembangkan perekonomian nasional yang merupakan usaha bersama berdasarkan azas kekeluargaan dan demokrasi ekonomi;

4) Sebagai mediator antara menyandang dana dengan penggunan dana, sehingga tercapai optimalisasi pemanfaatan harta;

5) Menguatkan kelompok-kelompok anggota, sehingga mampu bekerjasama melakukan kontrol terhadap koperasi secara efektif;

6) Mengembangkan dan memperluas kesempatan kerja;

7) Menumbuhkan-kembangkan usaha-usaha produktif anggota;

d. Dasar hukum koperasi syariah

1) Undang-Undang Dasar NKRI 1945 Amandemen ke 4 (empat);

2) Undang-Undang Nomor 25 tahun 1992 tentang Koperasi;

3) Undang-Undang Nomor 1 Tahun 2013 Tentang Tentang Lembaga Keuangan Mikro;

4) POJK No 12/POJK.5/2014 Tentang Perizinan Usaha dan Kelembagaan Lembaga Keuangan Mikro;

5) POJK No 12/POJK.5/2014 Tentang Perizinan Usaha dan Kelembagaan Lembaga Keuangan Mikro;

Dalam Pasal 30 Undang-undang Wakaf diatur mengenai lembaga keuangan syariah atas nama Nazhir harus mendaftarkan harta benda wakaf berupa uang kepada Menteri selambat-lambatnya 7 (tujuh) hari kerja sejak diterbitkannya Sertifikat Wakaf Uang. Dalam Pasal 24 ayat (1) Peraturan Pemerintah No 42 Tahun 2006 Tentang Pelaksanaan Undang-undang Wakaf dinyatakan bahwa LKS yang ditunjuk oleh Menteri sebagaimana dimaksud dalam Pasal 23 atas dasar saran dan pertimbangan dari BWI.

Menurut Latief, (2010) dan Wulandari \& Kassim (2016) sebagaimana dikutip oleh Gustani dan Dwi Aditya Ernawan (2016) Sebagai bagian dari fungsi intermediasi sosial, Lembaga Keuangan Mikro Ssyariah (LKMS) yang berbadan hukum koperasi dapat melakukan kegiatan maal dalam rangka pemberdayaan anggota dan masyarakat di bidang sosial dan ekonomi. Kegiatan maal dilakukan 
Vol. 2 No. 2 Juli 2020

melalui penghimpunan dan pengelolaan dana zakat, infak, sedekah, wakaf, dan dana sosial lainnya sesuai peraturan perundangan dan prinsip syariah. Dalam hal wakaf, LKMS dapat menjadi pengelola (nadzir) wakaf tunai dengan menginvestasikannya pada sektor yang tidak bertentangan dengan syariah.

Selanjutnya Gustani dan Dwi Aditya Ernawan (2016) mengutip pendapat Alfalisyado (2014) dan Satria, Burhan, \& Manzilati (2015) bahwa Bentuk LKMS di Indonesia yang banyak ditemukan diantaranya adalah Baitul Maal wa Tamwil (BMT) yang berbadan hukum koperasi. BMT yang secara pengawasan dan pengaturan berada dibawah Kementrian Koperasi dan UKM disebut Koperasi Simpan Pinjam dan Pembiayaan Syariah (KSPPS). Sedang BMT yang pengawasan dan pengaturannya dibawah Otoritas Jasa Keuangan (OJK) disebut Lembaga Keuangan Mikro Syariah (LKMS).

Berikut gambar tentang model pengelolaan wakaf uang yang dilakukan melalui Koperasi Syariah, baik itu KSPPS maupun LKMS atau BMT (Gustani dan Dwi Aditya Ernawan, 2016):

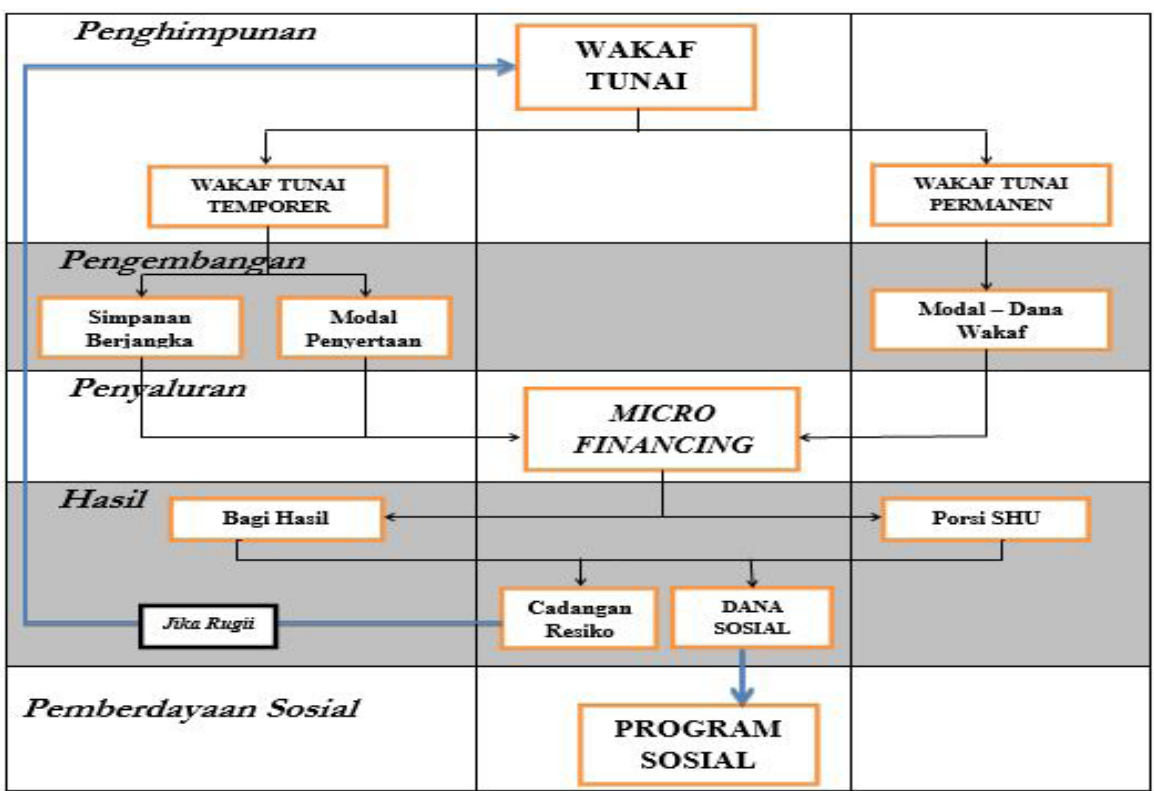

\section{Pengembangan Wakaf Tunai Melalui Koperasi Syariah}

Di Indonesia sebagai negara berkembang, sektor usaha mikro, kecil, dan menengah (UMKM) merupakan pemeran usaha dalam proporsi usaha nasional yang 
Vol. 2 No. 2 Juli 2020

paling besar. Asosiasi Usaha Mikro Kecil dan Menengah Indonesia (AKUMINDO) merilis data bahwa pada tahun 2019 kontribusi sector UMKM terhadap Produk Nasional Bruto (PDB) tumbuh 5\% sehingga mencapai 65\% atau sekitar Rp. 2.394.5 triliun. Salah satu jenis LKM yang saat ini mulai pesat perkembangannya adalah Lembaga Keuangan Mikro Syariah dalam bentuk koperasi syariah atau yang lebih dikenal dengan sebutan baitul maal wa tamwil (BMT). Menurut Permodalan BMT (PBMT) Ventura sebagai asosiasi BMT di Indonesia, tahun 2015, jumlah BMT yang tersebar di Indonesia berjumlah sekitar 4.500 BMT dengan aset mencapai Rp 16 triliun dan melayani hampir 3,7 juta anggota. Sebuah lembaga yang memiliki jaringan yang sangat luas dan mengakar kuat pada masyarakat Indonesia yang juga memiliki peran sentral dalam pengembangan dana filantropy Islam sebagaimana diuraikan di atas.

\section{Financial Technology (Fintech)}

Financial Technology (Fintech) adalah penggunaan teknologi dalam sistem keuangan yang menghasilkan produk, layanan, teknologi, dan/atau model bisnis baru. ${ }^{12}$ Selain itu, definisi menurut The Oxford Dictionary ${ }^{13}$ financial technology is Computer programs and other technology used to support or enable banking and financial services". Penyelenggaraan teknologi finansial terdiri dari beberapa kategori sebagai berikut: ${ }^{14}$ Sistem pembayaran, Pendukung pasar, Manajemen investasi dan manajemen risiko, Pinjaman, pembiayaan, dan penyediaan modal, Jasa finansial lainnya.

Penyelenggara teknologi finansial adalah setiap pihak yang menyelenggarakan teknologi finansial. ${ }^{15}$ Melalui PBI No.19/12/PBI/2017 tentang Penyelenggaraan Teknologi Finansial, Bank Indonesia mengatur mengenai kewajiban pendaftaran di Bank Indonesia bagi Penyelenggara Teknologi Finansial yang melakukan kegiatan sistem pembayaran. Kewajiban pendaftaran tersebut dikecualikan bagi Penyelenggara Jasa Sistem Pembayaran yang telah memperoleh izin dari Bank Indonesia dan bagi

12 Bank Indonesia, www.bi.go.id diunduh pada tanggal 9 Juni 2020 Pukul 13.00 WIB

13 Financial Technology dan Lembaga Keuangan, http://nofieiman.com/wpcontent/images/financial-technology-lembaga-keuangan.pdf diunduh pada tanggal 9 juni 2020 Pukul 14.23 WIB

14 Ibid.

15 Ibid. 
Vol. 2 No. 2 Juli 2020

Penyelenggara Teknologi Finansial yang berada dibawah kewenangan otoritas lain. ${ }^{16}$

Secara umum bentuk dasar financial technologi yang dislenggarakan oleh perusahaan fintech adalah sebagai berikit: ${ }^{17}$

\begin{tabular}{|c|c|c|}
\hline No. & Proses Bisnis & Bentuk Interaksi \\
\hline 1. & $\begin{array}{llll}\begin{array}{l}\text { Pembayaran } \\
\text { payment })\end{array} & (\text { digital } & \text { wallets, } & P 2 P \\
\end{array}$ & \multirow{2}{*}{$\mathrm{C} 2 \mathrm{C}$} \\
\hline 2. & $\begin{array}{l}\text { Investasi (Equity crowdfunding, } P 2 P \\
\text { lending) }\end{array}$ & \\
\hline 3. & $\begin{array}{l}\text { Pembiayaan (crowdfunding, micro-loans, } \\
\text { credit facilities) }\end{array}$ & \multirow[t]{2}{*}{ B2C } \\
\hline 4. & Asuransi (risk management) & \\
\hline 5. & $\begin{array}{l}\text { Lintas-proses (big } \\
\text { predictive modeling) }\end{array}$ data analysis, & \multirow[t]{2}{*}{ B2B } \\
\hline 6. & Infrastruktur (security) & \\
\hline
\end{tabular}

Adapun peranan fintech, yaitu sebagai berikut: ${ }^{18}$

1. Memberi solusi struktural bagi pertumbuhan industri berbasis elektronik (ecommerce),

2. Mendorong pertumbuhan usaha kecil dan menengah serta lahirnya wirausahawan (entrepreneur) baru,

3. Mendorong usaha kreatif (seperti artis, musisi, pengembang aplikasi, dsb.) untuk meraih distribusi pasar yang luas (critical mass),

4. Memungkinkan pengembangan pasar, terutama yang masih belum terlayani jasa keuangan dan perbankan konvensional (unbanked population).

\section{Tanggung Jawab Nadzir dalam Pengelolaan Wakaf Uang Berbasis Fintech Pada}

\section{Koperasi Syariah.}

Pengelolaan wakaf uang berbeda dengan pengelolaan wakaf selain uang seperti tanah dan bangunan. Pengelolaan wakaf uang hanya dapat dilakukan oleh nazhir yang memenuhi persyaratan nazhir sesuai Undang-undang Wakaf dan Peraturan Pemerinth No 42 Tahun 2006 Tentang Pelaksanaan Undang-undang Wakaf serta telah terdaftar sebagai

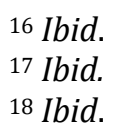

17 Ibid.

18 Ibid. 
Vol. 2 No. 2 Juli 2020

nazhir wakaf uang sebagaimana diatur dalam Peraturan BWI No. 2 Tahun 2010 tentang Nazhir Wakaf Uang. Berdasarkan data BWI pada Oktober tahun 2019 jumlah nazhir wakaf uang yang terdaftar pada BWI mencapai 224 lembaga (data BWI Oktober 2019) yang terdiri dari BWI, Perkumpulan seperti PBNU, Yayasan seperti Daaruttauhid dan Koperasi Syariah baik KSU maupun KSPPS. Dalam praktiknya nazhir pengelola wakaf uang tidak lepas dari permasalahan, seperti jangka waktu wakaf uang sementara, wakif yang tidak memenuhi syarat sah wakif (tidak cakap hukum) dan masalah pertanggungjawaban nazhir dalam pengelolaan wakaf uang itu sendiri. Dalam sub bab ini peneliti akan menguraikan mengenai tanggungjawab nazhir dalam pengelolaan wakaf uang mealui fintech. Mengenai tanggungjawab nazhir, secara eksplisit dinyatakan dalam Pasal 42 Undang-undang Wakaf $^{19}$ dimana nazhir bertanggungjawab atas pengelaolaan wakaf itu sendiri dan sebagai kompensasinya nazhir mendapatkan hak maksimal $10 \%$ dari hasil bersih pengelolaan harta wakaf tersebut sementara $90 \%$ hasilnya disalurkan kepada beneficiary (mauquf alaih) yang berhak menerima manfaat wakaf. ${ }^{20}$

Hak pengelolaan atas wakaf uang yang dimiliki nazhir bagaimanapun juga didasarkan pada hukum perjanjian yang kemudian melahirkan perikatan. Dalam hal ini ikrar wakaf yang dinyatakan oleh wakif menjadi dasar hukum (legal standing) nazhir untuk melakukan perbuatan hukum terhadap obyek wakaf (mauquf bih) termasuk dalam hal ini pengelolaan wakaf uang dalam portopolio pengelolaan wakaf yang dimiliki oleh nazhir. Berdasarkan prinsip kebebasan berkontrak, maka wakif dan nazhir dapat membuat segala macam kesepakatan sepanjang memenuhi syarat sahnya perjanjian, baik syarat subyektif yaitu cakap hokum dan sepakat, maupun syarat obyektif yaitu hal tertentu dan kausa halal/sesuatu yang tidak bertentangan dengan norma agama, hukum, kesusilaan dan kepatutan.

19 Pasal 42 Undang-undang wakaf: " Nazhir wajib mengelola dan mengembangkan harta benda wakaf sesuai dengan tujuan, fungsi dan peruntukannya" bahkan dalam Pasal 45 Undang-undang wakaf sesuai dengan tanggungjawabnya, nazhir dapat diberhentikan dan diganti dengan nazhir lain apabila, huruf d " tidak melaksanakan tugasnya sebagai nazhir dan/atau melanggar ketentuan larangan dalam pengelolaan dan pengembangan harta benda wakaf seuai dengan ketentuan peraturan perundang-undangan yang berlaku"

${ }^{20}$ Lihat Pasal 12 Undang-undang wakaf. 
Vol. 2 No. 2 Juli 2020

Pada prinsipnya, harta benda wakaf adalah harta yang didermakan oleh wakif dan dikelola oleh nazhir untuk kemudian digunakan agar memberikan sebesar-besarnya manfaat bagi masyarakat dengan catatan sesuai dengan keinginan wakif dan sesuai dengan aturan perundang-undangan. Hal tersebut sejalan dengan pendapat para ahli hukum Islam sebagaimana disampaikan oleh H.M. Salim Umar' ${ }^{21}$

Dengan demikian yang tetap dijaga dalam harta benda wakaf tidak hanya sebatas kepada keberadaan benda wakaf itu sendiri, akan tetapi lebih daripada itu yang lebih penting adalah nilai kemanfaatan dari aset wakaf yang dikelola oleh nazhir. Dalam hal ini nazhir mempunyai kepentingan yang sangat besar demi terjaganya kemanfaatan harta benda wakaf itu sendiri. Dalam pengelolaan wakaf, nazhir memiliki keleluasaan untuk mengalokasikan dana wakaf pada berbagai model pengembangan pengelolaan harta wakaf yang tidak bertentangan dengan hukum dan memenuhi kriteria akad syariah.

Mengenai hal tersebut secara eksplisit diatur dalam Pasal 43 ayat (1) Undangundang Wakaf yang menyatakan: "Pengelolaan dan pengembangan harta benda wakaf oleh nazhir sebagaimana dimaksud dalam Pasal 42 dilaksanakan sesuai dengan prinsip syariah”. Selanjutnya dipertegas dengan Pasal 45 ayat (2) PP No. 42 Tahun 2006 tentang Pelaksanaan Undang-undang No. 41 Tahun 2004 tentang Wakaf yang menyatakan: "Dalam mengelola dan mengembangkan harta benda wakaf sebagaimana dimaksud pada ayat (1) untuk memajukan kesejahteraan umum, Nazhir dapat bekerjasama deng an pihak lain sesuai dengan prinsip syariah"

Adapun model-model pengembangan pengelolaan harta wakaf produktif lebih lanjut diuraikan dalam penjelasan Pasal 43 ayat (2) Undang-undang Wakaf yang menyatakan bahwa :

"Pengelolaan dan pengembangan harta benda wakaf dilakukan secara produktif antara lain dengan cara pengumpulan, investasi, penanaman modal, produksi, kemitraan, perdagangan, agrobisnis, pertambangan, perindustrian, pengembangan teknologi, pembangunan gedung, apartemen, rumah susun, pasar swalayan, pertokoan, perkantoran, sarana pendidikan ataupun sarana kesehatan yang tidak bertentangan dengan syariah"

${ }^{21}$ Wawancara mendalam yang dilakukan oleh peneliti bersama Prof. Dr. H.M. Salim Umar MA, adalah Ketua Komisi Fatwa Majelis Ulama Indonesia Jawa Barat 
Vol. 2 No. 2 Juli 2020

Berkaitan dengan pengelolaan wakaf uang nazhir dapat menempuhi beberapa model pengembangan yaitu: Pertama, pembelian saham perusahaan Go Public dalam kategori LQ 45 melalui Pasar Modal; Kedua, pembelian sukuk untuk proyek strategis yang dijamin pemerintah; Ketiga, melalui skema investasi dalam bentuk penyertaan modal yang dikonversikan pada saham perusahaan; Keempat, melalui kerjasama pembiayaan sektor riil dengan akad mudharabah, musyarakah atau murabahah, dll.

Pada skema pertama risiko yang ditanggung oleh nazhir dapat dikatakan hampir tidak ada, karena investasi tersebut berada pada jaminan pemerintah. Pada skema kedua, sesungguhnya nazhir memiliki risiko yang sangat besar, akan tetapi hukum Pasar Modal Indonesia telah menetapkan adanya Lembaga Penjamin Syariah yang meminimalisir risiko bagi nazhir. Dilibatkannya Lembaga Penjamin Syariah apabila diperlukan sebagaimana dinyatakan dalam Pasal 43 ayat (3) Undang-undang Wakaf bahwa: Dalam hal pengelolaan dan pengembangan harta benda wakaf yang dimaksud pada ayat (1) diperlukan penjamin, maka digunakan lembaga penjamin syariah.

Pada skema ketiga, dimana nazhir menempatkan dana wakaf pada bidang usaha sebagai penyertaan modal baik dalam perusahaan yang dikelola sendiri oleh nazhir maupun perusahaan lain yang menjadi pasangan usaha nazhir. Dalam hal ini, selain keuntungan yang dapat menambah nilai manfaat wakaf, sebagai pengelola nazhir memiliki risiko yang besar apabila perusahaan tersebut mengalami kerugian atau bahkan dipailitkan yang mana saham perusahaan dapat menjadi jaminan untuk kerugian atau obyek sitaan, padahal Pasal 40 Undang-undang Wakaf menyatakan bahwa harta benda wakaf yang sudah diwakafkan dilarang: 1. dijadikan jaminan; 2. disita; 3. dihibahkan; 4. dijual; 5. diwariskan; 6. ditukar; atau 7. dialihkan dalam bentuk pengalihan hak lainnya.

Pada skema yang keempat, dimana nazhir mengalokasikan dana wakaf dalam pembiayaan sector riil, maka risiko yang dihadapi adalah pembiayaan bermasalah (Non Ferforming Financing atau NPF) yang dapat mengkibatkan berkurangnya atau bahkan hilangnya dana wakaf.

Apabila terjadi masalah sebagaimana diuraikan di atas, maka dalam perspektif hukum dapat disikapi dengan beberapa pendekatan., yaitu: 
Vol. 2 No. 2 Juli 2020

1. Apabila masalah yang dimasudkan muncul karena kesalahan dari pihak nazhir, baik karena kesengajaan maupun kelalaian dan tidak diperhatikannya prinsip kehati-hatian, maka nazhir dapat dimintakan pertanggungjawaban sesuai dengan tanggungjawab yang didasarkan pada kesalahan (based on fault). Hal tersebut diatur dalam Kitab Undang-Undang Hukum Perdata (selanjutnya disingkat KUHPerdata) khususnya terdapat dalam Pasal 1365, 1366 dan 1367. Prinsip ini menyatakan, seseorang baru dapat dimintakan pertanggung-jawaban secara hukum jika ada unsur kesalahan ${ }^{22}$ yang dilakukannya. Pasal 1365 KUHPerdata yang lazim dikenal sebagai pasal tentang perbuatan melawan hukum, mengharuskan terpenuhinya empat unsur pokok, yakni:

a. Adanya perbuatan melawan hukum;

b. Adanya unsur kesalahan;

c. Adanya kerugian yang diderita;

d. Adanya hubungan kausalitas antara perbuatan dan kerugian.

Dengan demikian apabila beberapa ketentuan yang berkaitan dengan prinsip tanggung jawab berdasarkan kesalahan dapat dibuktikan, maka nazhir diharuskan mengganti kerugian dan mengembalikan dana wakaf tersebut.

2. Apabila masalah sebagaimana disebutkan muncul bukan karena kesalahan nazhir, maka dalam hal ini nazhir tidak dapat dimintakan pertanggungjawabannya, baik secara moral maupun secara hokum. Artinya ganti kerugian atas harta wakaf tersebut dibebankan kepada pihak lain yang bekerjasama dengan nazhir sebagaimana ketentuan mengenai wanprestasi atau perbuatan melawan hokum yang diatur dalam KHPerdata.

\section{PENUTUP}

\section{Simpulan}

Apabila masalah dalam pengelolaan wakaf uang seperti terjadinya pembiayaan bermasalah atau NPF, terjadi karena kesalahan nazhir, baik karena kesengajaan maupun

22 Yang dimaksud kesalahan adalah unsur yang bertentangan dengan hukum. Pengertian "hukum" tidak hanya bertentangan dengan undang-undang, tetapi juga kepatutan dan kesusilaan dalam masyarakat. Lihat Idem, hlm. 92. 
Vol. 2 No. 2 Juli 2020

kelalaian dan atau karena tidak diperhatikannya prinsip kehati-hatian, maka nazhir dapat dimintakan pertanggungjawaban sesuai dengan tanggungjawab yang didasarkan pada kesalahan (based on fault). Hal tersebut diatur dalam Kitab Undang-Undang Hukum Perdata (selanjutnya disingkat KUHPerdata) khususnya terdapat dalam Pasal 1365, 1366 dan 1367. Prinsip ini menyatakan, seseorang baru dapat dimintakan pertanggung-jawaban secara hukum jika ada unsur kesalahan yang dilakukannya. Apabila beberapa ketentuan yang berkaitan dengan prinsip tanggung jawab berdasarkan kesalahan dapat dibuktikan, maka nazhir diharuskan mengganti kerugian dan mengembalikan dana wakaf tersebut. Sebaliknya apabila masalah sebagaimana disebutkan muncul bukan karena kesalahan nazhir, maka nazhir tidak dapat dimintakan pertanggungjawabannya, baik secara moral maupun secara hukum. Ganti kerugian atas harta wakaf dibebankan kepada pihak lain yang bekerjasama dengan nazhir sebagaimana ketentuan mengenai wanprestasi atau perbuatan melawan hokum yang diatur dalam KHPerdata

\section{Rekomendasi}

1. Harus dilakukan review terhadap Undang-undang Wakaf sehingga dapat lebih mengakomodasi perkembangan dalam pengelolaan wakaf termasuk di antaranya fintech syariah

2. Nazhir, selain memahami ilmu fikih khsususnya tentang wakaf, juga dituntut untuk memahami ilmu mengenai pengelolaan investasi dan hokum serta koitmmen terhadap prinsip kehati-hatian sebagaimana diterapkan dalam sebuah perusahaan dengan konsep Good Corporate Governance

3. Koperasi syariah harus diberi akses lebih luas lagi dalam pengelolaan wakaf uang sebagaimana akses yang juga diberikan kepada perbankan syariah sebagai lembaga keuangan syariah penerima wakaf uang sehingga pemberdayaan umat yang menjadi tanggungjawab semua pihak dapat dilakukan lebih menyeluruh, terlebih koperasi syariah yang notabene sangat erat interaksinya dengan UMKM.

\section{DAFTAR PUSTAKA}

\section{Buku}

Departemen Agama Republik Indonesia, Direktorat Pemberdayaan Wakaf, Jakarta: 2006 
Vol. 2 No. 2 Juli 2020

Euis Amalia, Keadilan Ditributif dalam Ekonomi Islam, Penguatan LKM dan UKM di Indonesia, Jakarta: rajagrafindo Persada, 2009.

Ismail Nawawi, Fikih Muamalah Kontemporer, Bogor: Ghalia Indah, 2012

Juhaya S. Praja, Perwakafan di Indonesia; Sejarah, Pemikiran, Hukum, dan Perkembangannya, Bandung: Yayasan Piara, 1997

Ramudi Arifin, Koperasi Sebagai Perusahaan, Jatinangor: Ikopin Press, 2013.

Riza Risyanti dan Roesmidi, Pemberdayaan Masyarakat, Sumedang: Alqaprint Jatinangor,2006

Syaikh Muhammad bin Shalih al-Utsaimin, Panduan Wakaf dan Wasiat Menurut AlQuran dan al-Sunnah, Jakarta: Pustaka Imam Asy-Syafi'i, 2008.

\section{Perundang-Undangan}

Undang-Undang Dasar NKRI 1945 Amandemen ke 4 (empat)

Undang-Undang Nomor 25 tahun 1992 tentang Perkoperasian

Undang-Undang Nomor 41 Tahun 2004 Tentang Wakaf

Undang-Undang No 11 Tahun 2008 Tentang Informasi dan Transaksi Elektronik

Undang-undang Nomor 11 Tahun 2008 Tentang Informasi dan Transaksi Elektronik

Undang-Undang Nomor 1 Tahun 2013 Tentang Tentang Lembaga Keuangan Mikro

POJK No 12/POJK.5/2014 Tentang Perizinan Usaha dan Kelembagaan Lembaga Keuangan Mikro.

\section{Sumber Lain}

Amir Mu'allim, Ijtihad Ekonomi Dalam Pengelolaan Aset Wakaf, Yogyakarta: Jurnal Al'Adalah, Volume 14 Nomor 2, 2017.

Menteri Perencanaan Pembangunan Nasional/Kepala Badan Perencanaan Pembagunan Nasional, Indonesia Menuju Pusat Ekonomi dan Keuangan Syariah Dunia, Materi High Level Discussion pada Muktamar IV Ikatan Ahli Ekonomi Islam(IAEI), Jakarta 23 Agustus 2019

Rahmat Dahlan, Analisis Kelembagaan Badan Wakaf Indonesia, http://journal.uinjkt.ac.id, Vol. 6 (1), 2016.

Ginandjar Kartasasmita, Pemberdayaan Masyarakat: Konsep Pembangunan ang Berakar Pada Masyarakat (Orasi Ilmiah Menteri Negara Perencanaan Pembangunan Nasional /Ketua Bappenas pada Saresehan DPD Golkar Tk.1 Jawa timur 1997). Lihat http://file.upi.edu/Direktori/FIP/JUR._PEND._LUAR_SEKOLAH/19520725197 8031-ACE_SURYADI/09PemberdayaanMasyarakat.pdf

https://kementeriankoperasi.com/pengertian-koperasi-syariah/

Bank Indonesia, www.bi.go.id

Financial Technology dan Lembaga Keuangan, http://nofieiman.com/wpcontent/images/financial-technology-lembaga-keuangan.pdf. 